\begin{tabular}{l}
$\begin{array}{c}\text { ホソカ研究助成 } \\
\text { 成果報 }\end{array}$ Hosokawa Powder Technology Foundation ANNUAL REPORT KONA \\
\hline
\end{tabular}

18115

\title{
CFRP から回収した炭素繊維を利用した高機能性材料の開発 \\ Development of Multi-functional Materials Using Carbon Fibers Recycled from CFRP
}

\author{
研究代表者 Research leader: 山本 徹也 Tetsuya YAMAMOTO \\ 名古屋大学大学院工学研究科 准教授 \\ Graduate School of Engineering, Nagoya University, Associate Professor \\ E-mail: yamamoto.tetsuya@material.nagoya-u.ac.jp
}

抄 録

本研究では炭素繊維強化プラスチック（CFRP）から回収した炭素繊維 $(\mathrm{RCF})$ とバガスを利用して, 活性炭を作製し，その比表面積を測定して物性を評価した。

CFRP から臨界繊維長 $700 \mu \mathrm{m}$ 未満の RCF をカッターミルで回収した. バガスのセルロースの加水 分解反応に扔いて, $\mathrm{RCF}$ 表面にはカルボキシル基とヒドロキシ基がセルロースの加水分解反応の 触媒として機能すると考えられる官能基の量が存在した，RCF とバガスを複合化させる方法を， 水中での超音波照射により実施した。硫酸を賦活剤としてバガスから活性炭を作製する工程で, 七 ルロースを加水分解させることが微細孔の発達には不可欠であることがわかった．また，硫酸が高 温領域でバガス中の分解除去されたセルロースの孔に含浸し, 孔の鋳型として働くことで微細孔の 発達に寄与していることがわかった，バガスの炭化が十分に起こる温度以上で熱処理を行う場合で は，RCF を添加することで比表面積の増加が最大で $20 \%$ 見込めることが分かった.

\begin{abstract}
In this study, activated carbon was prepared using bagasse and carbon fiber (RCF) recycled from carbon fiber reinforced plastic (CFRP), and its specific surface area was measured to evaluate its properties.

RCF with a critical fiber length of less than $700 \mu \mathrm{m}$ was obtained from CFRP using a cutter mill. In the hydrolysis reaction of cellulose in bagasse, the amount of functional groups, such as the carboxyl group and hydroxyl group, on the RCF surface was enough to function as a catalyst for the hydrolysis reaction of cellulose. The fabrication method for composite of RCF and bagasse was performed by ultrasonic irradiation in water. Hydrolysis of cellulose in the process of activated carbon from bagasse using sulfuric acid as an activator proved to be essential for making micropores. It was also found that sulfuric acid impregnated the pores of cellulose decomposed and removed in bagasse at high temperature and contributed to making micropores by acting as a mold for the pores. It was found that the addition of RCF could increase the specific surface area by up to $20 \%$ when the heat treatment was performed at a temperature higher than the temperature at which bagasse was sufficiently carbonized.
\end{abstract}




\section{研究背景と目的}

材料の高機能化が進み, われわれの生活を豊 かになる一方で，使い終わった材料の廃棄物処 理について多くの問題があげられている。本研 究では, サトウキビの搾りかすであるバガスと 今後大量に廃棄されるであろう炭素繊維強化プ ラスチック（CFRP）の有効利用（Yamamoto T. et al., 2017）について検討した.

サトウキビは熱帯から亜熱帯にかけて広い地 域で栽培されており, 年間発生量は世界中で 2 億 8 千万トンに及ぶ. サトウキビから砂糖を搾 汁したりバイオエタノールを抽出したりした後 に発生する茎や葉などの大量のバガスは世界中 で大量に発生するが，その大部分が廃棄されて いるという現状である。この廃棄バガスが長期 間放置された場合, 自然発火する可能性があり 問題となっている.

また現在，CFRPのリサイクル技術が求めら れている。CFRPの母材樹脂にはエポキシ系樹 脂を主とした熱硬化性樹脂が使われているた め, 廃棄 CFRP から新たな CFRP を再成型する ことは困難である。よって廃棄 CFRP から炭素 繊維のみを回収し，フィラーとして再利用する 方法が一般的である。その手法には高温で樹脂 のみを熱分解除去する熱分解法, 化学分解法 (化 学的に樹脂を溶解させて炭素繊維を回収する方 法）がある。どちらの手法においても重要とな るのは, 回収した炭素繊維が強化繊維として再 利用できることである。廃棄 CFRP から樹脂を 取り除いて得られる炭素繊維の長さには限りが ある。これはおよそ $2 \sim 10 \mathrm{~m}$ と考えられる。 仮に，これらから未使用の炭素繊維と同等の力 学特性をもつ炭素繊維が回収できたとしても, この長さでは織物やプリプレグの生産に再利用 することはできない，しかし，短繊維の再利用 方法については, 繊維長が $25 〜 50 \mathrm{~mm}$ あれば 不織布に利用可能である。繊維長が $10 \mathrm{~mm}$ 以 下であれば，ポリプロピレンやポリアミドとコ ンパウンドする射出成形用の強化材として利用 できる。しかし，炭素瀻維を強化材として用い
る際に，炭素繊維の強度が発現する繊維長（限 界繊維長）を回収した炭素繊維が下回っている 場合は，強化材としての再利用が難しい。この 炭素繊維の限界繊維長は $700 \mu \mathrm{m}$ 程度であるが, 強化材以外の再利用方法は検討中である.さら に，リサイクルを繰り返すと繊維長が短くなる という問題がある. 以上の背景から本研究では, このような限界繊維長を下回る炭素繊維の再利 用方法に焦点を当て，これとバガスを組み合わ せた活性炭製造方法を検討した。

\section{研 究 方 法}

リサイクル炭素繊維（RCF）を応用してバガ スを原料とした高比表面積の活性炭の作製を目 指した。この時, RCFの効果について述べる 前に, 先にどのようにして微細孔の発達した活 性炭を作製するかについて述べる。原料内部に $\mathrm{nm}$ オーダーの微細孔を生成する反応や操作を 賦活と言い, この微細孔の生成により内部比表 面積が増大して炭素材料に吸着能力を付与する ことができる。本研究では，この賦活剤として 硫酸を使用した。硫酸は原料バガス中のセル ロースの加水分解反応の触媒として働く。セル ロースを取り除いて発生した孔が微細孔に応用 できると考えられる，植物を原料として活性炭 を製造する場合，一般的には植物に含まれる揮 発成分が放出された箇所や植物が元々持ってい た導管や繊維質などの骨格構造が残り，その箇 所を基にして活性炭が多孔質になる.バガスは, セルロース，ヘミセルロース，リグニンの天然 高分子で構成されるリグノセルロース系バイオ マスである，バイオエタノールの原料となるセ ルロースを回収する手法を糖化という。なかで も酸糖化法は, 硫酸や塩酸などの酸を触媒とし て作用させ，リグノセルロース中の糖類を加水 分解する方法である。本研究では, エ夕ノール 製造と関連付けるため, 酸糖化法により発生す る残椬（硫酸リグニン）を活性炭の前駆体とし た，植物系原料に微細孔を形成するためには， 植物中のセルロースを酸糖化法により分解する 
必要がある。このとき，セルロースの加水分解 反応をより効率良く進行させることができれ ば，より吸着性能の高い活性炭が得られると考 えられる。硝酸溶液下で行うセルロース試料の 加水分解反応の効率化に関する既往の研究で, サリチル酸系触媒を加えるとセルロースがグル コースに転換した割合が上昇すると報告されて いる。また，他研究では，表面にカルボキシル 基（R-COOH）とフェノール性ヒドロキシ基 （Ar-OH）を併せ持った活性炭を固体触媒とし て利用するとセルロースの加水分解率が上昇し たと報告されている. 以上の研究から, カルボ キシル基とフェノール性ヒドロキシ基が, セル ロース加水分解反応の触媒として働いているこ とが考えられる。

炭素繊維の表面には含酸素官能基が存在す る。製造工程で炭素繊維表面にヒドロキシ基 $(-\mathrm{OH})$, カルボキシル基 $(-\mathrm{COOH})$, ケトン基 (=CO) などの含酸素官能基を導入する表面酸 化処理が行われている。これらはエポキシ樹脂 と化学結合するので, 炭素繊維一樹脂界面の接 着性の向上を目的としている。 RCFの利用法 として，炭素繊維表面に存在するこれらの含酸 素官能基を，バガス中のセルロース加水分解反 応の触媒として用いることを検討した，本研究 で活性炭の原料となるバガスは，株式会社沖縄 黒糖のバガスを使用した。 バガス繊維のサイズ 範囲は小さいもので繊維長 $10 \mathrm{~mm}$ 未満, 繊維 幅 1 〜 mm, 大きなもので䋊維長 $50 \mathrm{~mm}$ 以上, 幅 $10 \mathrm{~mm}$ 以上であった（図 1)。活性炭の製造 に使用する電気管状炉のサイズより，バガスを さらに細かく粉砕する必要があり, 家庭用 ジューサーを用いて粉砕を行った。図 1 に粉砕 したバガス繊維を示す。その繊維長は $10 \mathrm{~mm}$ 以下，䋊維幅は $1 \sim 2 \mathrm{~mm}$ 程度の均一なバガス 繊維が得られたことがわかる。このバガス繊維 から活性炭を製造した。

本研究で対象とする RCFを，その繊維長が 臨界繊維長 $(700 \mu \mathrm{m})$ 未満のものとすると決 定した。このような粉体を製造する方法として, 最も簡便な方法は粉砕である。そのため, せん
だん力を利用した中砕機である連続式カッター ミル（IKA，MF10ベーシック）を用いて CFRPの粉砕を行った. 100 メッシュの金網を 通過した粉砕物を RCFとした。回収した RCF の繊維長分布をデジタルミクロスコープ（KH8700, 株式会社 HiROX）を用いて測定し, $100 \mu \mathrm{m}$ ごとの割合を算出した（図 2). RCF 表 面の樹脂は走査型電子顕微鏡 FE-SEM（SM7500F，日本電子）により観察した。 CFRP 及 びRCFの重量減少を示差熱熱重量同時測定装 置（TG/DTA）（STA7200, 株式会社 日立ハイ テクサイエンス）を用いて，昇温速度 $10^{\circ} \mathrm{C} / \mathrm{min}$ で $700^{\circ} \mathrm{C}$ まて昇温させた時のそれぞれの重量 減少量を測定し, カッターミルで除去できた樹 脂量を算出した，その結果, カッターミルによっ て CFRPに含まれる樹脂の $41 \%$ を除去するこ とができた。

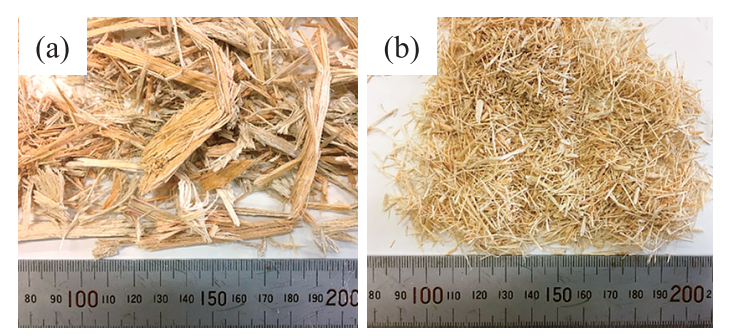

Fig. 1 Photos of bagasse (a) before and (b) after the pulverization.

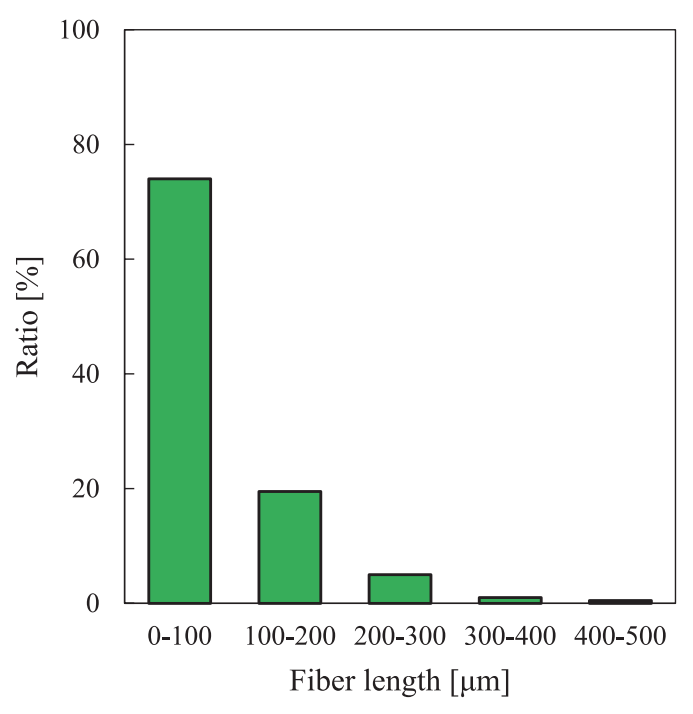

Fig. 2 Size distribution of RCF recycled from CFRP. 


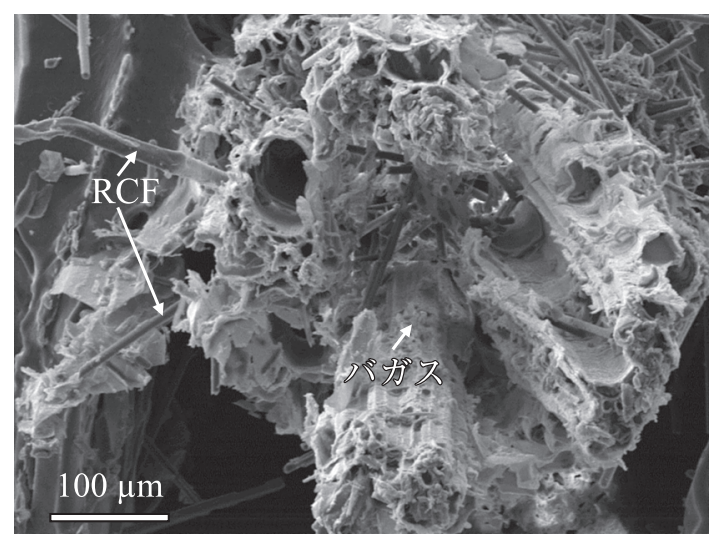

Fig. 3 SEM image of composite of RCF and bagasse.

RCF を触媒として利用する場合, RCF とバ ガスの接触性が重要であると考えられる，本研 究で用いた RCF は，その䋊維長が $700 \mu \mathrm{m}$ 未満 のものとしており, 接触性の向上にもなる。さ らに，接触性の向上を図るために，RCF とバ ガスを以下の方法で複合化させた。内容量 $100 \mathrm{ml}$ のスクリュー管を用い, バガス繊維と RCF，水を投入し，超音波洗浄機（US-5KS, 株式会社エスエヌデイ）を用いて，15 分間超 音波照射して，バガスと RCFの複合体を得た (図 3).

\section{研 究成 果}

セルロースを加水分解する酸処理 $\left(150^{\circ} \mathrm{C}\right.$ で $24 \mathrm{~h}$ 保持する工程）が細孔特性に与える影響を 検討した。このとき, 酸処理の有無による影響 のみを調べる，前駆体の $\mathrm{RCF}$ 含有量を $0 \mathrm{wt} \%$ とした. process（A）ではバガス中のセルロー スを加水分解させるため $150^{\circ} \mathrm{C} て ゙ ~ 24 \mathrm{~h}$ 保持す る工程が存在, process（B) では $150^{\circ} \mathrm{C}$ で保持 することなく, 炭化·賦活温度 $T$ まで加熱した。 温度 $\mathrm{T}$ を $300,400,500^{\circ} \mathrm{C}$, 昇温速度を $5^{\circ} \mathrm{C} / \mathrm{min}$ とした。また，加えた硫酸濃度は $10 \%$ とした。 process（A）では炭化・賦活温度 $T$ を $500^{\circ} \mathrm{C}$, 昇温速度を $5^{\circ} \mathrm{C} / \mathrm{min}$, process (C) では炭化・ 賦活温度 $T$ を $600,700,800,900,1000^{\circ} \mathrm{C}$, 昇温速度を $10^{\circ} \mathrm{C} / \mathrm{min}$ とした。作製した活性炭

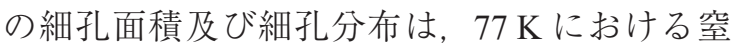

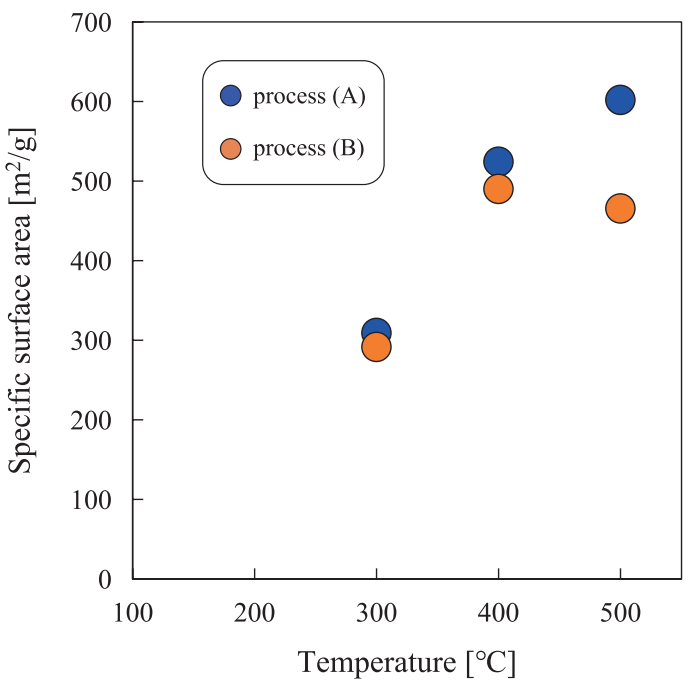

Fig. 4 Comparison activated carbon through process (A) with activated carbon through process (B) at each temperature, $T$.

素吸着及び吸着等温線から求めた。等温線は比 表面積／細孔分布測定装置（BELSORP- mini II, MicrotracBEL Corp.）を用いて測定した。測定 前の前処理として, 真空加熱前処理装置（BELS ORP-vac II, MicrotracBEL Corp.) を用いて, $573 \mathrm{~K}$, 真空下 (10 Pa 未満) で脱気を $2 \sim 3$ 時 間行った。

いずれの炭化・賦活温度の場合でも，比表面 積はprocess（A）で作製した活性炭の方が process（B）で作製した活性炭よりも大きくなっ た（図 4). よって, 酸でセルロースを加水分 解する操作がミクロ孔の発達に寄与していると 考えられる。バガスから除去されたセルロース が元々存在した孔がある方が，ミクロ孔が発達 すると考えられる。ミミロ孔の径は $2 \mathrm{~nm}$ 未満 であり，セルロースの孔がそのまま細孔になる とは考えにくい. 酸処理のみを行ったサンプル のBET 比表面積は $0.759 \mathrm{~m}^{2} / \mathrm{g}$ であった. よって, セルロース由来の孔がその状態のままミクロ孔 になるのではなく, 酸処理後に行う炭化・賦活 処理によって微細孔が発達すると考えられる。

process（A）は酸処理を行い, その状態のま ま炭化・賦活処理を行って, 洗浄, 乾燥して活 性炭を得るプロセスであるのに対して, process 
（C）は酸処理を行った後, 洗浄, 乾燥させた ものを炭化・賦活処理して活性炭を得るプロセ スである. process（C）において600,700, $800^{\circ} \mathrm{C}$ で炭化・賦活処理を行った活性炭では吸

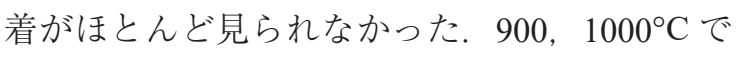
はやや吸着が見られた。一般的に，Tが高くな るほど比表面積が増大する，ある温度を超える と比表面積は増加しなくなり，逆に低下する。 process $(\mathrm{C})$ の場合では, $800^{\circ} \mathrm{C}$ までの温度で はミクロ孔が発達せず, $900^{\circ} \mathrm{C}$ 以上の温度でミ クロ孔が形成されると推察される. process (A) で $500^{\circ} \mathrm{C}$ で炭化・賦活処理を行った活性炭の 比表面積は $414.5 \mathrm{~m}^{2} / \mathrm{g}$ であったが, process (C) で作製した活性炭で一番大きな比表面積は $126.2 \mathrm{~m}^{2} / \mathrm{g}$ であった. process（A）と（C）の違 いは, 高温領域での硫酸の存在である. process （C）では酸処理後に洗浄を行うことで硫酸を 除去しているのに対して, process（A）では酸 処理後に洗浄を行わず，その状態のまま昇温さ せているため, 高温領域で硫酸が存在する.よっ て, 硫酸が熱処理中に粒子内部に残っているこ とでミクロ孔の鋳型として働いていると考えら れる。この作用は塩化亜鉛やリン酸では明らか になっており, 硫酸についても同様の作用をも つことが予測される。 process（A）が活性炭の 作製に適したプロセスであると言える.

本研究では, リグノセルロースから活性炭を 作製する工程で, RCFがバガス炭の細孔特性 に与える影響が重要である。よって，RCFを 加えて作製した活性炭の比表面積の評価は $S_{\mathrm{b}}$ を比較し, RCF が細孔特性に与える影響につ いて考察した。

process（A）で $T$ を $300 ， 500,700^{\circ} \mathrm{C}$ で作製 した活性炭のBET 比表面積 $S_{\mathrm{b}}$ を図 5 に示した。 活性炭の吸着等温線から, いずれの活性炭もミ クロ孔を有した活性炭であることが示唆され た。 $500^{\circ} \mathrm{C}$ 及び $700^{\circ} \mathrm{C}$ で作製した活性炭ではヒ ステリシスがほとんど見られなかったのに対し て， $300^{\circ} \mathrm{C}$ で作製した活性炭ではヒステリシス が見られた。これより， $300^{\circ} \mathrm{C} て ゙$ 作製した活性 炭の方が $500^{\circ} \mathrm{C}$ 及び $700^{\circ} \mathrm{C}$ で作製した活性炭

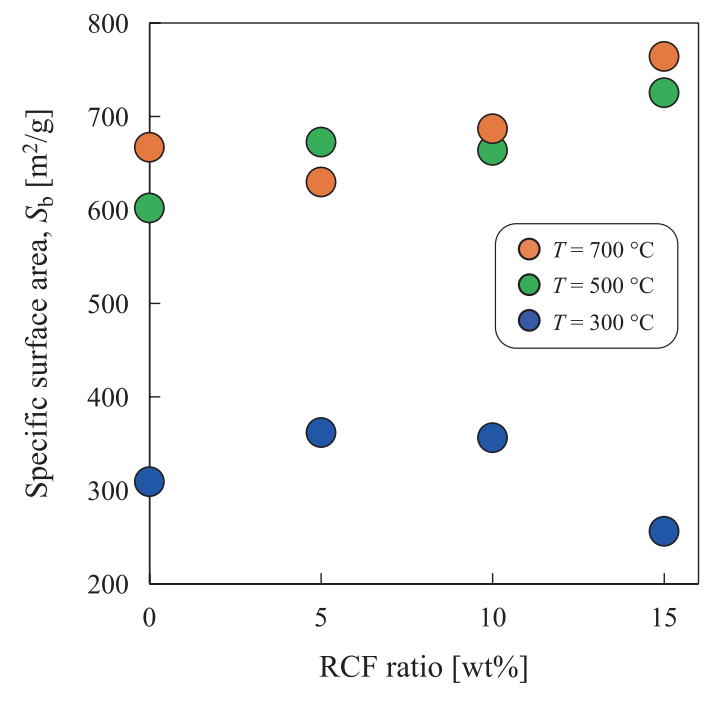

Fig. 5 Influence of the concertation of RCF on specific surface area of the activated carbon.

よりもメソ孔容積が大きいと考えられる，低圧 部分での吸着量を見ると， $300^{\circ} \mathrm{C}$ で作製した活 性炭に比べて $500^{\circ} \mathrm{C}$ 及び $700^{\circ} \mathrm{C} て ゙$ 作製した活 性炭の方が明らかに大きな吸着量を示した。 こ れより, ミクロ孔容積は $300^{\circ} \mathrm{C}$ で作製した活 性炭よりも $500^{\circ} \mathrm{C}$ 及び $700^{\circ} \mathrm{C} て ゙$ 作製した活性 炭の方が大きいと考えられる，Tは大きくなれ ば比表面積が増大し, ある温度を超えると一定 になるか, あるいは減少し始める。よって, $\mathrm{RCF}=0 \mathrm{wt} \%$ 時での比表面積が熱処理温度の上 昇とともに大きくなっている現象は理解でき る。バガスを構成する主要成分はセルロース, ヘミセルロース，リグニンである。それぞれの 熱分解温度の範囲はへミセルロースが 200 $300^{\circ} \mathrm{C}$, セルロースが $240 \sim 400^{\circ} \mathrm{C}$, リグニン が $280 \sim 900^{\circ} \mathrm{C}$ の範囲である. RCF が $0 \mathrm{wt} \%$ 時, $300^{\circ} \mathrm{C}$ で熱処理を行った活性炭と $500^{\circ} \mathrm{C}$ で作製 した活性炭では比表面積に大きな差が生じた. これはセルロースの熱分解が起きることで $500^{\circ} \mathrm{C}$ で作製した活性炭の比表面積が大きく なったと考えられる。 RCF 量が作製した活性 炭の比表面積に与える影響をバガスの炭化が十 分に起こる $T=500^{\circ} \mathrm{C}$ の活性炭の比表面積の結 果をもとに考察した.

次に，十分に炭化が起こる温度よりも低い 
$T=300^{\circ} \mathrm{C}$ で作製した活性炭と十分に炭化が起 こる温度よりも高い $T=700^{\circ} \mathrm{C}$ で作製した活性 炭の結果から，それぞれの場合で RCF 量が比 表面積に与える影響について考察した，炭化が 十分に起こる $T=500^{\circ} \mathrm{C}$ の場合, $\mathrm{RCF}$ 含有量の 増加とともに比表面積 $S_{\mathrm{b}}$ が増加していく傾向 が得られた。これより， RCFの添加がバガス 炭の比表面積の増加に有効であると考えられ る. $\mathrm{RCF}$ がバガス中のセルロースの加水分解 を促進させる触媒として機能したためと考えら れる。一方, $T=700^{\circ} \mathrm{C}$ の時, $\mathrm{RCF}$ 量が $5 \mathrm{wt} \%$ 時では一時的に比表面積が減少したが, $10 \mathrm{wt} \% ， 15 \mathrm{wt} \%$ 時では $0 \mathrm{wt} \%$ 時よりも比表面 積が増加した結果となった。 $T$ の上昇に伴い比 表面積が増加していき，ある所定の温度を超え ると比表面積の増加が緩やかになり，やがて減 少し始める傾向は以下のように説明される，炭 化が十分に起こる温度以上での熱処理により， 活性炭粒子全体に熱収縮が起きる。これにより 活性炭中の細孔は押しつぶされて小さくなる， $T$ を高くするにつれて比表面積が増大傾向にあ る間は, この現象が起きて細孔が小さくなるこ とで比表面積が増大する。また，それにより吸 着能も上昇する，比表面積の増加傾向が緩やか になり, 減少し始める温度領域での熱処理では, 熱収縮による細孔の収縮の程度が大きくなり， 細孔が完全に潰れてしまうことで比表面積の減 少が始まる。 $T=500^{\circ} \mathrm{C}$ よりも $T=700^{\circ} \mathrm{C}$ の方 が比表面積 $S_{\mathrm{b}}$ は RCF が $5 \mathrm{wt} \%$ 時以外では大き くなっているため, $T=700^{\circ} \mathrm{C}$ はまだ比表面積 が増加傾向にある温度領域であると考えられ る，炭化が十分起こる温度より高い温度で熱処 理を行っても，この温度領域内であれば RCF を添加することで比表面積の増大が見込める． RCF を添加することでバガス中のセルロース の加水分解が促進されるため, セルロースの孔 が多くなる。この孔自体の大きさはミクロフィ ブリルの大きさを考えるとミクロ孔よりも大き いと考えられるが，熱収縮によってミクロ孔相
当のサイズとなり $T=700^{\circ} \mathrm{C}$ の方が $T=500^{\circ} \mathrm{C}$ よりも比表面積の大きな活性炭を得られたと考 えられる。

$T=300^{\circ} \mathrm{C}$ の時, $\mathrm{RCF}$ 含有量が $5 \mathrm{wt} \%$ になる と比表面積が増加したが，10 wt \% になると減 少し， $15 \mathrm{wt} \%$ 時には $0 \mathrm{wt} \%$ 時よりも下回った. ミクロ孔の発達に欠かせないと考えられるセル ロースの熱分解除去は，セルロースの熱分解開 始温度である $T=300^{\circ} \mathrm{C}$ の場合，その熱分解は ほとんど起きないと考えられる。酸処理により セルロースを加水分解し, 重合度を低下させる ことで, 熱分解が可能になると考えられるので, $\mathrm{RCF}$ 量が $10 \mathrm{wt} \%$ 以上でセルロースの加水分解 反応の触媒として作用するならば， $5 \mathrm{wt} \%$ 時で は $0 \mathrm{wt} \%$ 時とセルロースの重合度は変わらず, $10 \mathrm{wt} \%$ では重合度が低下し始め，15 wt\% の時 は $10 \mathrm{wt} \%$ の時よりも重合度が低下していると 考えられる. RCF が $5 \mathrm{wt} \%, 10 \mathrm{wt} \%$ の時は, 比表面積に大きく寄与するミクロ孔に相当する サイズのミクロフィブリルが熱分解除去され， その孔がそのまま活性炭のミクロ孔となり， $10 \mathrm{wt} \%$ 時に比べて比表面積が増大したと考え られる. $10 \mathrm{wt} \%$ 時では, $5 \mathrm{wt} \%$ 時よりもセルロー スの重合度を低下させて, 除去されるミクロ フィブリルの大きさが $5 \mathrm{wt} \%$ 時に比べてやや 大きくなり，比表面積が小さくなった，RCF が $15 \mathrm{wt} \%$ の時は, $10 \mathrm{wt} \%$ 時に比べてセルロー スの重合度が小さくなり，熱分解除去されたミ クロフィブリルが多く，その孔がメソ孔相当の サイズであったため, ミクロ孔ではなくメソ孔 の発達が進み，0 wt\% 時に比べて大きく比表面 積が小さくなったと考えられる。

\section{参考文献}

Yamamoto T., Makino Y., Uematsu K., Improved mechanical properties of PMMA composites: dispersion, diffusion and surface adhesion of recycled carbon fiber fillers from CFRP with adsorbed particulate PMMA, Advanced Powder Technology, 28 (2017) 2774-2778. https://doi.org/10.1016/j.apt.2017.08.003 